\title{
Menadione Toxicity in Cultured Rat Cortical Astrocytes
}

\author{
Kazuho Abe and Hiroshi Saito \\ Department of Chemical Pharmacology, Faculty of Pharmaceutical Sciences, The University of Tokyo, Tokyo 113, Japan \\ Received July 22, $1996 \quad$ Accepted September 9, 1996
}

\begin{abstract}
We examined the effect of menadione on the morphology and viability of cultured astrocytes. Exposure of astrocytes to menadione induced a progressive cell death. The toxic effect of menadione was concentration- and time-dependent. Menadione toxicity was blocked by antioxidants, superoxide dismutase, catalase and iron chelators, indicating that superoxide anions $\left(\mathrm{O}_{2}^{-}\right)$, hydrogen peroxide $\left(\mathrm{H}_{2} \mathrm{O}_{2}\right)$ and hydroxyl radicals $(\mathrm{OH})$ are all involved in menadione toxicity. Menadione cytotoxicity should be useful as a model for studying the mechanisms underlying oxidative injury in the brain and for the screening of drugs that may attenuate cell damage caused by oxidative stress.
\end{abstract}

Keywords: Menadione, Toxicity, Reactive oxygen species, Astrocyte, Culture

Recent evidence suggests that increased formation of reactive oxygen species is responsible for a variety of neurodegenerative disorders, including Alzheimer's disease, Parkinson's disease and amyotrophic lateral sclerosis, and for pathological conditions such as ischemia and excitotoxicity $(1-3)$. Reactive oxygen species involved in cytotoxicity are mainly superoxide anion $\left(\mathrm{O}_{2}{ }^{-}\right)$, hydrogen peroxide $\left(\mathrm{H}_{2} \mathrm{O}_{2}\right)$ and hydroxyl radical $\left({ }^{\circ} \mathrm{OH}\right)$. Although neurotoxic effects of reactive oxygen species have been extensively studied, the impact of oxidative stress on astrocytes is not well-understood. Since astrocytes are supposed to promote neuronal regeneration by producing neurotrophic factors around the locus of brain injuries $(4-6)$, it is important to study astrocytic responses to oxidative stress.

As an in vitro model of oxidative stress, some investigators have employed an exogenous free-radical-generating system such as hypoxanthine/xanthine oxidase $(7,8)$. However, the effect of reactive oxygen species generated outside the cells should be different from that inside the cells. Menadione (2-methyl-1,4-naphthoquinone), which is also designated vitamin $\mathrm{K}_{3}$, has been reported to enter the cells and generate $\mathrm{O}_{2}{ }^{-}$via one-electron-transfer reactions $(9-12)$. This agent could be useful for studying the effect of reactive oxygen species generated endogenously as a result of stress. In the present study, we therefore investigated the effect of menadione on the morphology and viability of cultured astrocytes, in comparison with the effect of exogenously applied $\mathrm{H}_{2} \mathrm{O}_{2}$.

\section{MATERIALS AND METHODS}

Basal culture medium used in the present study was a modified Eagle's medium containing $30 \mathrm{mM}$ glucose, 2 $\mathrm{mM}$ glutamine and $1 \mathrm{mM}$ pyruvate. Primary cultures of astrocytes were prepared from the cerebral cortices of 18day-old embryos of Wistar rats. After removal of the menings, the cortices were dissociated by trypsinization and pipetting as described previously (13). Cells were suspended in a medium supplemented with $10 \%$ fetal bovine serum and plated on uncoated $25 \mathrm{~cm}^{2}$ flasks at a density of 600,000 cells $/ \mathrm{cm}^{2}$. The culture medium was changed 12 hr after the plating and then every 3-4 days. The cells grew and became confluent after 10-14 days. At this point, more than $90 \%$ of the adherent cells exhibited the flattened, polygonal appearance typical of type I astrocytes. Non-astrocytes were detached from the flasks by shaking and removed by changing the medium. The remaining cells were dissociated by trypsinization $(0.1 \%$ trypsin $-0.04 \%$ EGTA) and plated on uncoated 96-well plates at a density of 10,000 cells $/ \mathrm{cm}^{2}$. After the cells became confluent (5-6 days after the plating), the medium was switched to serum-free medium, and experiments were initiated $24 \mathrm{hr}$ later. Test reagents were added to the culture medium.

Changes in cell morphology were assessed by microscopic examination, and cell viability was quantitatively measured by the modified 3-[4,5-dimethylthiazol-2-yl]2,5-diphenyltetrazolium bromide (MTT) reduction assay (14). For the MTT assay, the culture medium was 
replaced by serum-free medium containing $0.5 \mathrm{mg} / \mathrm{ml}$ MTT and then the incubation continued for $1 \mathrm{hr}$ at $37^{\circ} \mathrm{C}$. The dye MTT is converted into a purple formazan by the redox activity of living cells. After the medium was removed, the cells were solubilized by adding a solution containing $50 \%$ dimethylformamide and $20 \%$ sodium dodecyl sulfate ( $\mathrm{pH} 4.8$ ), and the amount of formazan product was determined by measuring its absorbances at 570 and $630 \mathrm{~nm}$. By microscopic examination, we confirmed that decrease in MTT reduction was parallel to cell death. In all assays, triplicate wells were used for each condition, and the averaged value was obtained. Each

\section{$100 \mu \mathrm{M}$ Menadione}

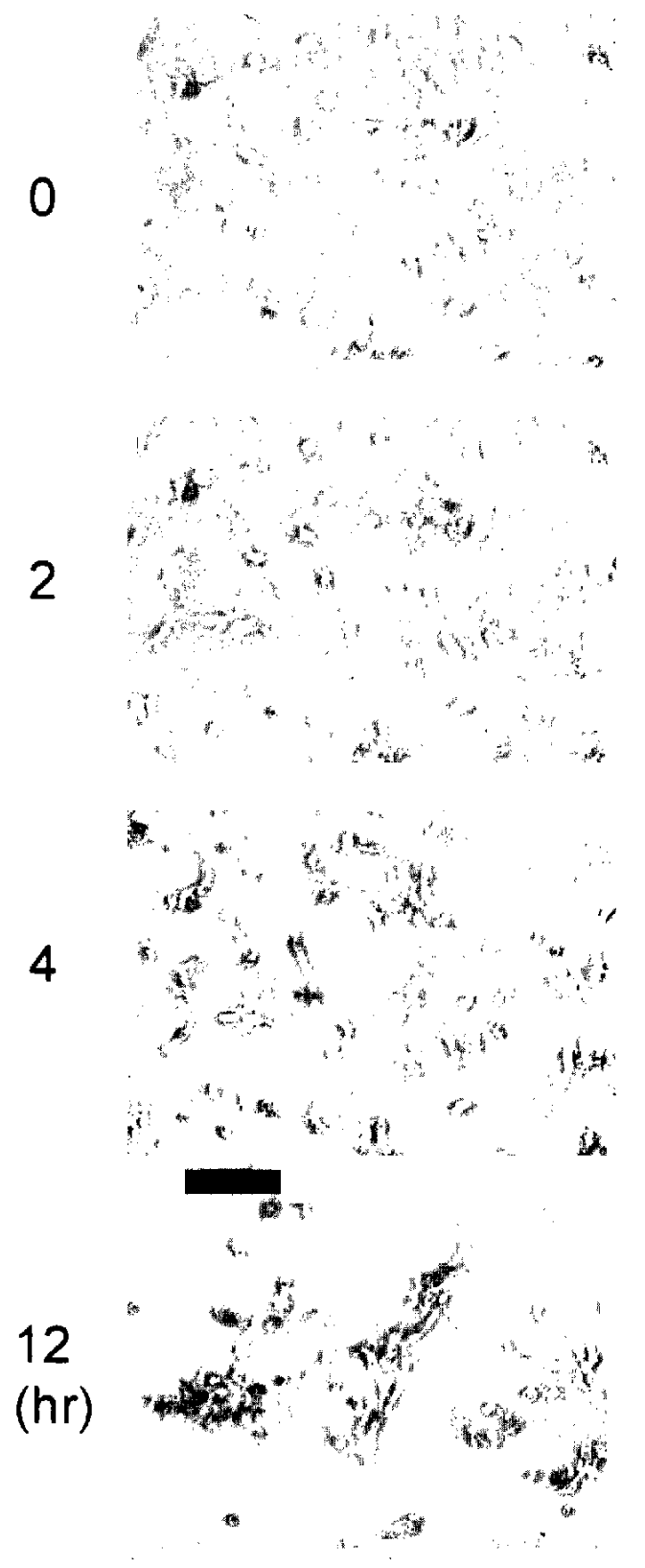

\section{$1 \mathrm{mM}$ Menadione}

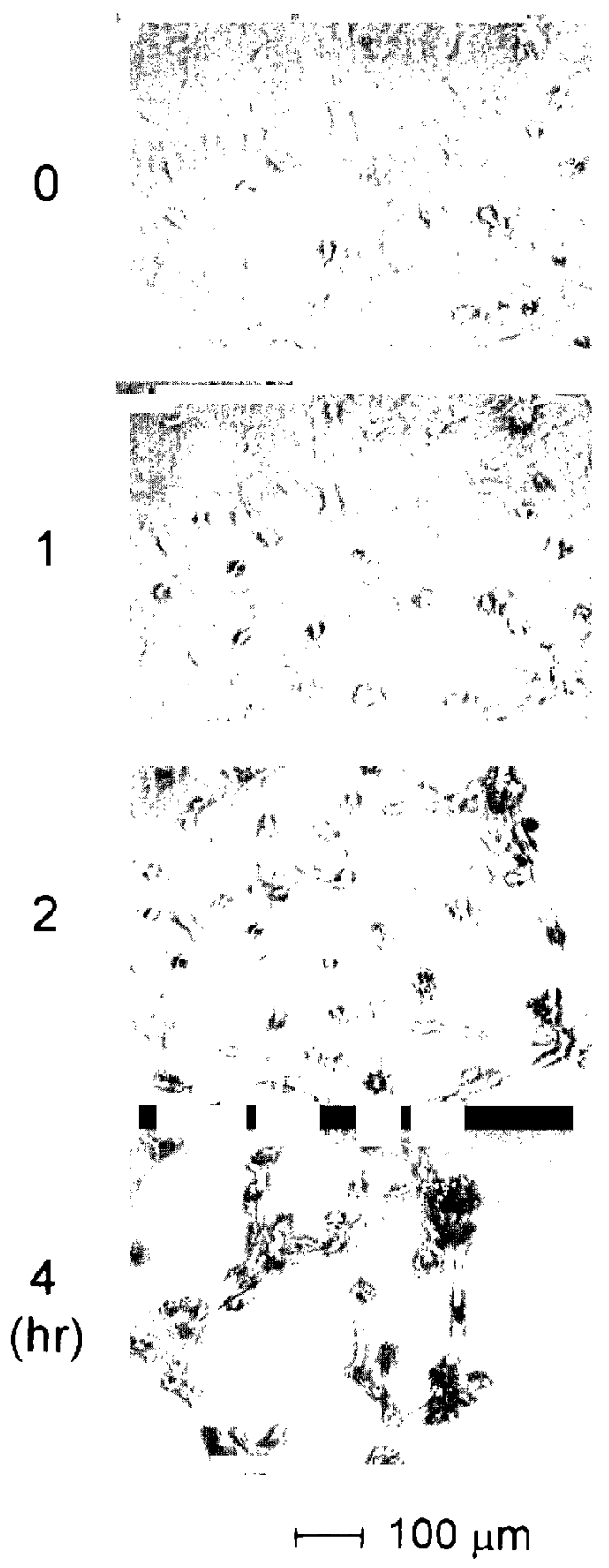

Fig. 1. Effect of menadione on morphology of cultured astrocytes. Menadione was added at a concentration of $100 \mu \mathrm{M}$ or $1 \mathrm{mM}$, and cells in the same field were photographed at the indicated time after addition of menadione. 
experiment was repeated in five separate cultures, and the data are finally presented as the mean \pm S.E.M. of five separate observations.

To check the purity of cultures, cells were fixed with 4\% paraformaldehyde and employed for immunocytochemical examination. After overnight incubation at $4{ }^{\circ} \mathrm{C}$ with monoclonal antibodies to glial fibrillary acidic protein (GFAP; Amersham, Little Chalfont, UK), cells were stained with a Vectastain Elite ABC kit (Vector, Burlingame, CA, USA), according to the manufacturer's instructions. More than $95 \%$ of the cells used for assays were identified as type I astrocytes by positivity for GFAP and by morphological characteristics.

Since menadione is insoluble in water, we used menadione sodium bisulphite, the water-soluble form of menadione. In preliminary experiments, we checked the effect of sodium metabisulfite $\left(\mathrm{Na}_{2} \mathrm{~S}_{2} \mathrm{O}_{5}\right)$, which yields sodium bisulfite $\left(\mathrm{NaHSO}_{3}\right)$ when dissolved in water. Sodium metabisulfite $(1-1000 \mu \mathrm{M})$ had no effect on morphology and viability of astrocytes. Thus the influence of the sodium bisulfite moiety is negligible in the present study. $\mathrm{H}_{2} \mathrm{O}_{2}$, propyl gallate, superoxide dismutase from bovine erythrocyte and $N, N, N^{\prime}, N^{\prime}$-tetrakis (2-pyridylmethyl) ethylenediamine (TPEN) were purchased from Wako

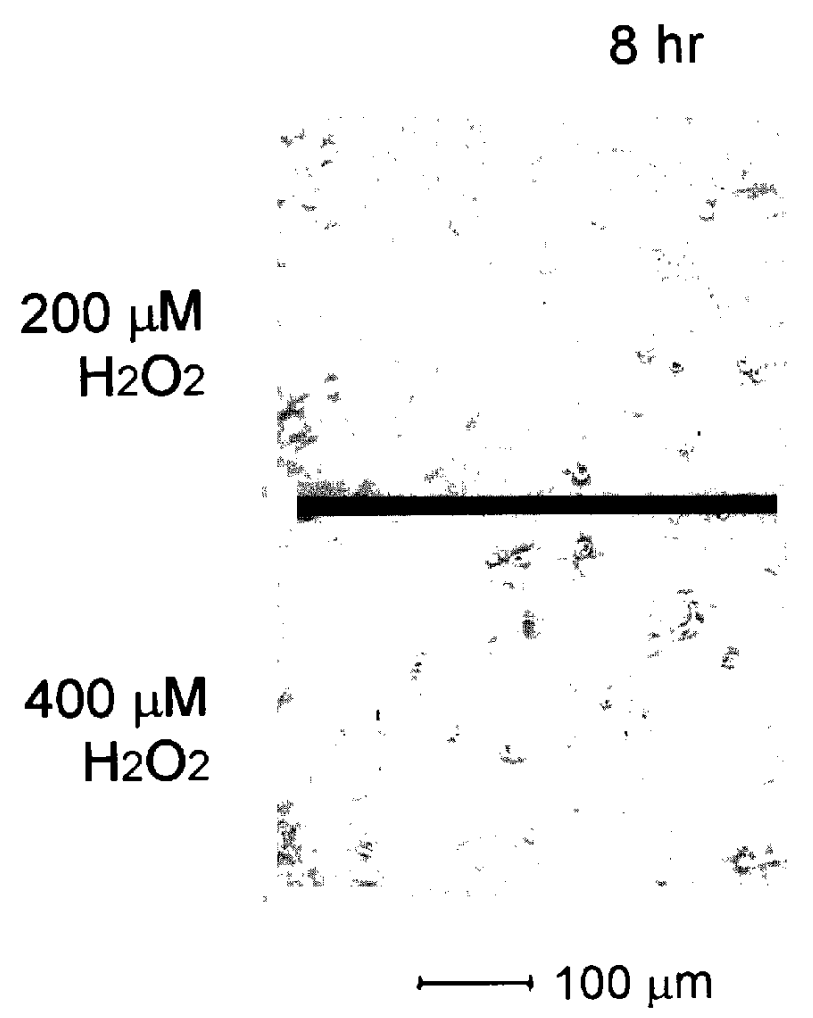

Fig. 2. Effect of exogenously applied $\mathrm{H}_{2} \mathrm{O}_{2}$ on morphology of cultured astrocytes. $\mathrm{H}_{2} \mathrm{O}_{2}(200$ or $400 \mu \mathrm{M})$ was added to the culture medium, and cells were photographed $8 \mathrm{hr}$ later.

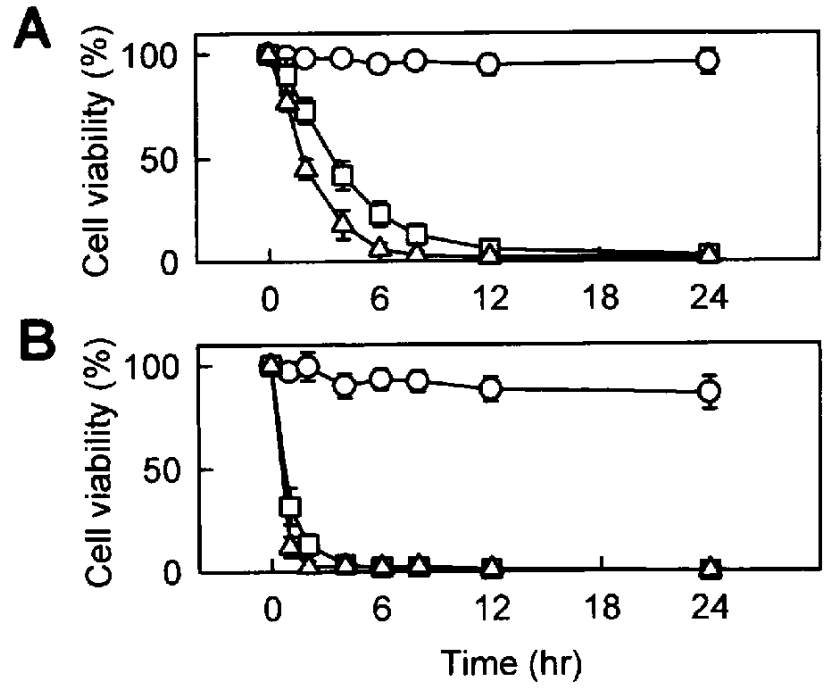

Fig. 3. Time course of toxicity of menadione (A: $\bigcirc, 10 \mu \mathrm{M} ; \square$, $100 \mu \mathrm{M} ; \triangle, 1 \mathrm{mM})$ and exogenously applied $\mathrm{H}_{2} \mathrm{O}_{2}(\mathrm{~B}: \bigcirc, 200 \mu \mathrm{M}$; $\Xi, 400 \mu \mathrm{M} ; \triangle, 800 \mu \mathrm{M})$. The abscissa indicates time after addition of menadione or $\mathrm{H}_{2} \mathrm{O}_{2}$. Cell viability was determined by the MTT reduction assay and expressed as a percentage of the control. The data represent the mean \pm S.E.M. of the determinations on five separate cultures.
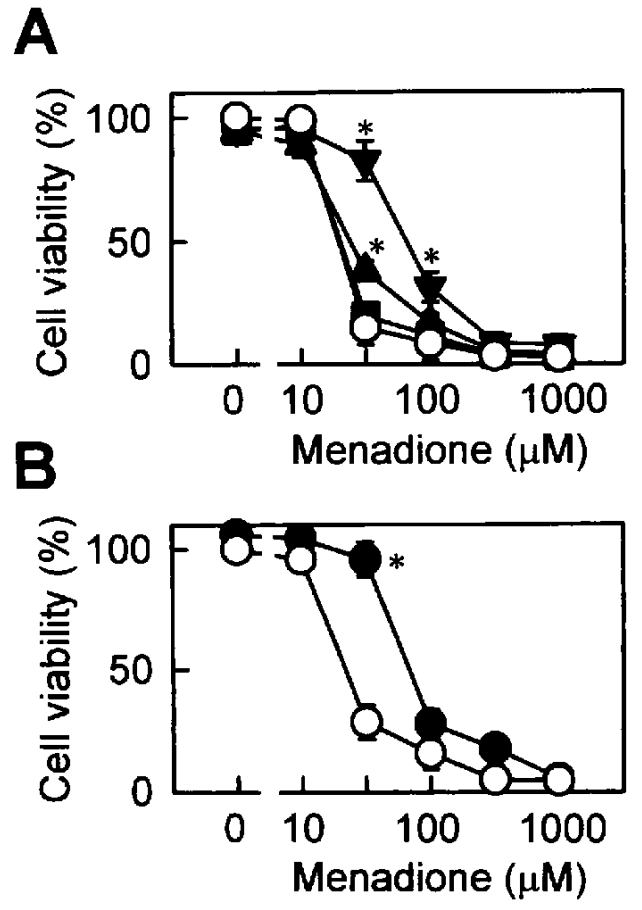

Fig. 4. Effects of antioxidants, propyl gallate (A: $\bigcirc$, control; $\mathbf{\square}$, $0.5 \mu \mathrm{M} ; \Delta, 5 \mu \mathrm{M} ; \boldsymbol{\nabla}, 50 \mu \mathrm{M}$ ) and $N$-acetylcysteine (B: $\bigcirc$, control; , $500 \mu \mathrm{M})$, on menadione toxicity. Antioxidants were added 30 min prior to addition of menadione, and the cells were exposed to menadione $(10-1000 \mu \mathrm{M})$ for $8 \mathrm{hr}$. Cell viability was determined with the MTT reduction assay and represent the mean \pm S.E.M. of five separate observations. Asterisks indicate significant differences from the control: ${ }^{*} \mathrm{P}<0.01$ (Duncan's multiple range test). 
Pure Chemical Industries, Ltd. (Osaka). N-Acetylcysteine, catalase from bovine liver, tert-butyl hydroperoxide and deferoxamine were purchased from Sigma Chemical Co. (St. Louis, MO, USA).

\section{RESULTS}

Exposure of astrocytes to menadione caused a progressive cell death. Figure 1 shows menadione-induced morphological changes of cultured astrocytes. When cells were exposed to $100 \mu \mathrm{M}$ menadione, apparent morphological changes were observed $2 \mathrm{hr}$ later. Cells gradually atrophied and were finally detached from the culture dishes. All cells were killed within $12 \mathrm{hr}$. Such morphological changes occurred earlier when higher concentrations were applied. Menadione at $1 \mathrm{mM}$ killed all cells within $6 \mathrm{hr}$.

Addition of $\mathrm{H}_{2} \mathrm{O}_{2}$ ( $400 \mu \mathrm{M}$ or more) also induced a progressive cell death, but morphological change induced by exogenous $\mathrm{H}_{2} \mathrm{O}_{2}$ was considerably different from that by menadione (Fig. 2). Cells seemed to have burst, and flattened cell membranes were left on the culture dishes. Another characteristic of exogenous $\mathrm{H}_{2} \mathrm{O}_{2}$ toxicity was that its concentration-effect relationship was very steep. More than $90 \%$ of the astrocytes were viable in the presence of $200 \mu \mathrm{M} \mathrm{H}_{2} \mathrm{O}_{2}$, but all cells were killed by 400 $\mu \mathrm{M} \mathrm{H} \mathrm{H}_{2} \mathrm{O}_{2}$. This means that twofold increase of $\mathrm{H}_{2} \mathrm{O}_{2}$ level is sufficient to induce cell death.

The effects of menadione and $\mathrm{H}_{2} \mathrm{O}_{2}$ on cell viability were quantitated with the MTT reduction assay, and the results are shown in Fig. 3. Menadione toxicity was seen at concentrations of more than $10 \mu \mathrm{M}$. The time course of menadione toxicity was slower than that of exogenous $\mathrm{H}_{2} \mathrm{O}_{2}$.

To determine if menadione toxicity is caused by oxidative stress, the effects of antioxidants on menadione toxicity were investigated. Antioxidants were added $30 \mathrm{~min}$ prior to addition of menadione, and the cells were exposed to menadione $(10 \mu \mathrm{M}-1 \mathrm{mM})$ for $8 \mathrm{hr}$. The antioxidant propyl gallate alone had no effect on cell viability, but significantly attenuated menadione toxicity (Fig. 4A). Similarly, another antioxidant, $N$-acetylcysteine, was effective in attenuating menadione toxicity (Fig. 4B).

To determine which oxygen species $\left(\mathrm{O}_{2}{ }^{-}, \mathrm{H}_{2} \mathrm{O}_{2}\right.$ or $\left.{ }^{\circ} \mathrm{OH}\right)$ are involved in menadione toxicity, we investigated the effects of scavengers for these reactive oxygens. First, $\mathrm{O}_{2}$ dismutates into $\mathrm{H}_{2} \mathrm{O}_{2}$ via a reaction catalyzed by the enzyme superoxide dismutase (SOD). If $\mathrm{O}_{2}{ }^{-}$is involved in menadione toxicity, then addition of SOD should attenuate the toxicity. As shown in Figs. 5 and 6A, menadione toxicity was attenuated by SOD. $\mathrm{H}_{2} \mathrm{O}_{2}$ toxicity was not affected by SOD (Fig. 6B), supporting that SOD

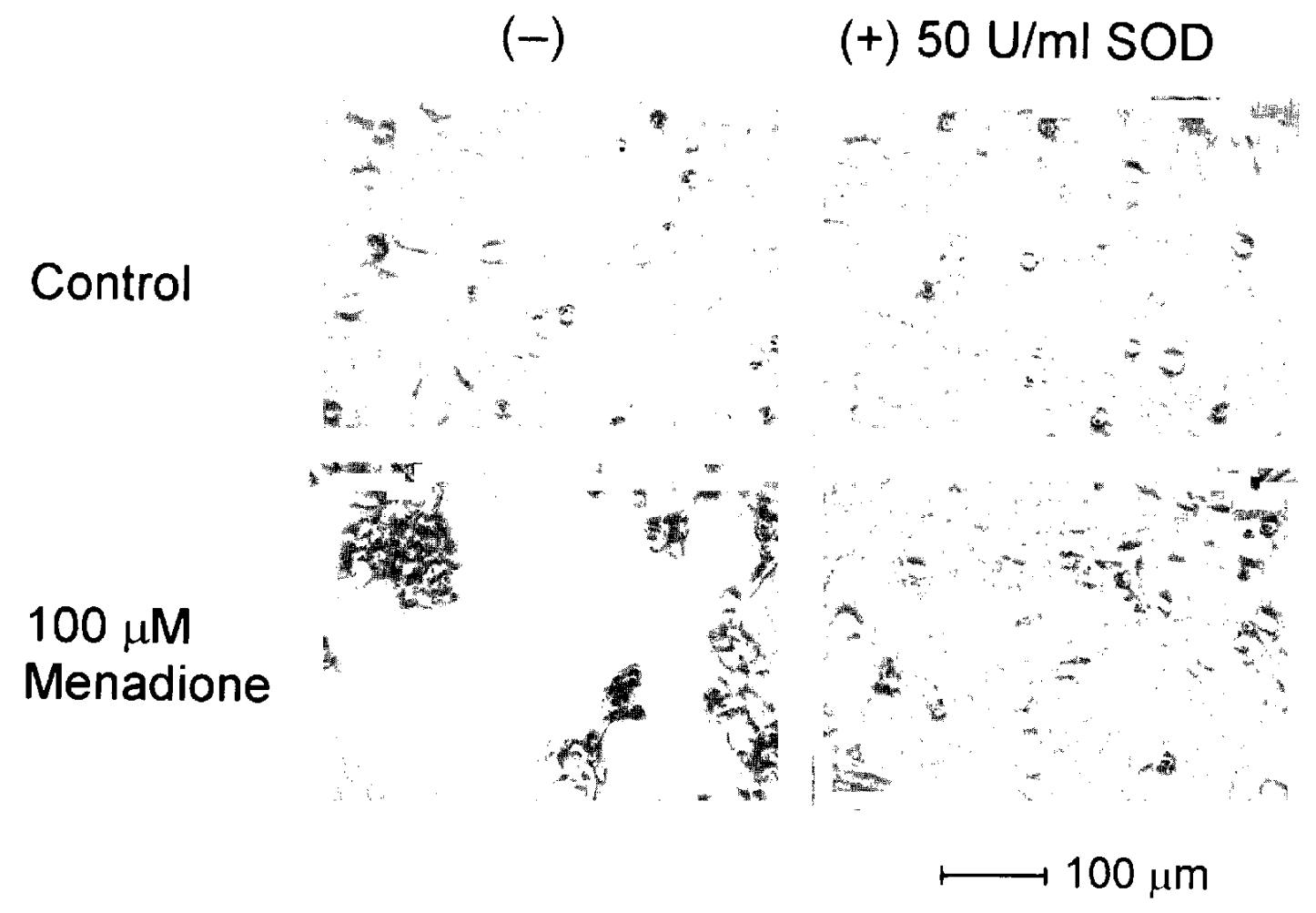

Fig. 5. Effects of menadione and SOD on morphology of cultured astrocytes. SOD $(50 \mathrm{U} / \mathrm{ml})$ was added $30 \mathrm{~min}$ prior to menadione, and cells were exposed to menadione $(100 \mu \mathrm{M})$ for $8 \mathrm{hr}$. 


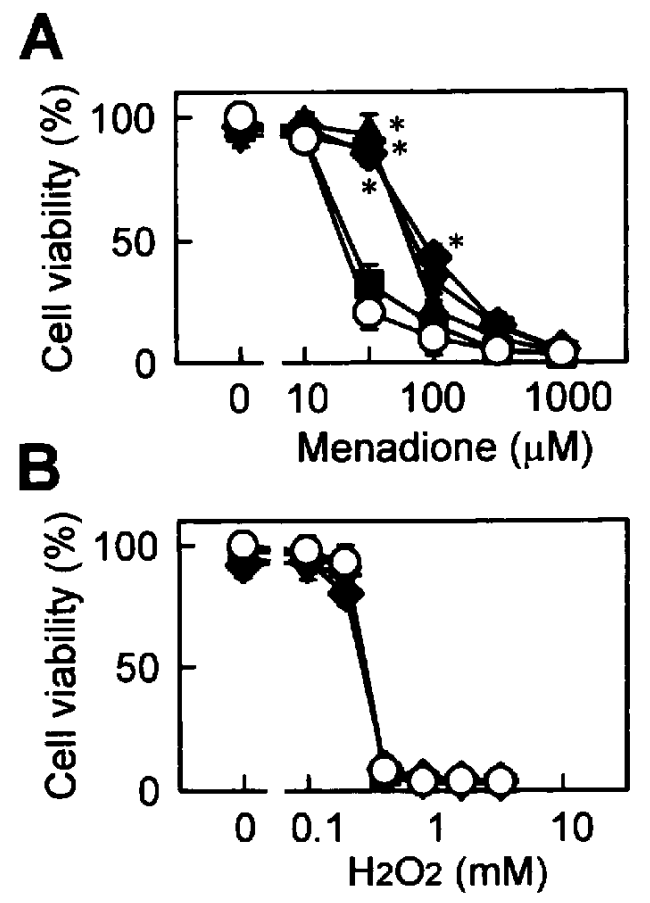

specifically blocked $\mathrm{O}_{2}^{-}$-mediated toxicity. Second, $\mathrm{H}_{2} \mathrm{O}_{2}$ is decomposed into $\mathrm{H}_{2} \mathrm{O}$ and $\mathrm{O}_{2}$ by the action of catalase. If $\mathrm{H}_{2} \mathrm{O}_{2}$ is involved in menadione toxicity, it should be attenuated by catalase. As shown in Figs. 7 and $8 \mathrm{~A}$, menadione toxicity was markedly attenuated by catalase. We confirmed that catalase was effective in attenuating exogenous $\mathrm{H}_{2} \mathrm{O}_{2}$ toxicity (Fig. $8 \mathrm{~B}$ ). It should be noted that catalase protected the cells against exogenous $\mathrm{H}_{2} \mathrm{O}_{2}$ more potently than against menadione. As shown in Fig. $8 \mathrm{C}$, catalase had no effect on toxicity induced by the lipid peroxidizing agent tert-butyl hydroperoxide $(15,16)$, supporting that catalase specifically blocked $\mathrm{H}_{2} \mathrm{O}_{2}$ mediated toxicity. Third, ${ }^{\circ} \mathrm{OH}$ is generated through the breakdown of $\mathrm{H}_{2} \mathrm{O}_{2}$ in the presence of ferric ions $\left(\mathrm{H}_{2} \mathrm{O}_{2}+\mathrm{Fe}^{2+} \rightarrow \mathrm{OH}^{-}+{ }^{\circ} \mathrm{OH}+\mathrm{Fe}^{3+}\right.$, the Fenton reaction; 17,18 ). If $\mathrm{OH}$ production is involved in menadione

Fig. 6. Effects of SOD $(O$, control; $\boldsymbol{\square}, 0.05 \mathrm{U} / \mathrm{ml} ; \boldsymbol{\Delta}, 0.5 \mathrm{U} / \mathrm{ml}$; V. $5 \mathrm{U} / \mathrm{ml} ; \diamond, 50 \mathrm{U} / \mathrm{ml}$ ) on astrocytic cell death induced by menadione (A) or exogenously applied $\mathrm{H}_{2} \mathrm{O}_{2}(\mathrm{~B})$. Cells were exposed to menadione or $\mathrm{H}_{2} \mathrm{O}_{2}$ for $8 \mathrm{hr}$, and then cell viability was determined by the MTT reduction assay. The data represent the mean \pm S.E.M. of five separate observations. ${ }^{*} \mathrm{P}<0.01$ vs control (Duncan's multiple range test).

\section{$(-) \quad(+) 200 \mathrm{U} / \mathrm{ml}$ Catalase}

\section{Control}
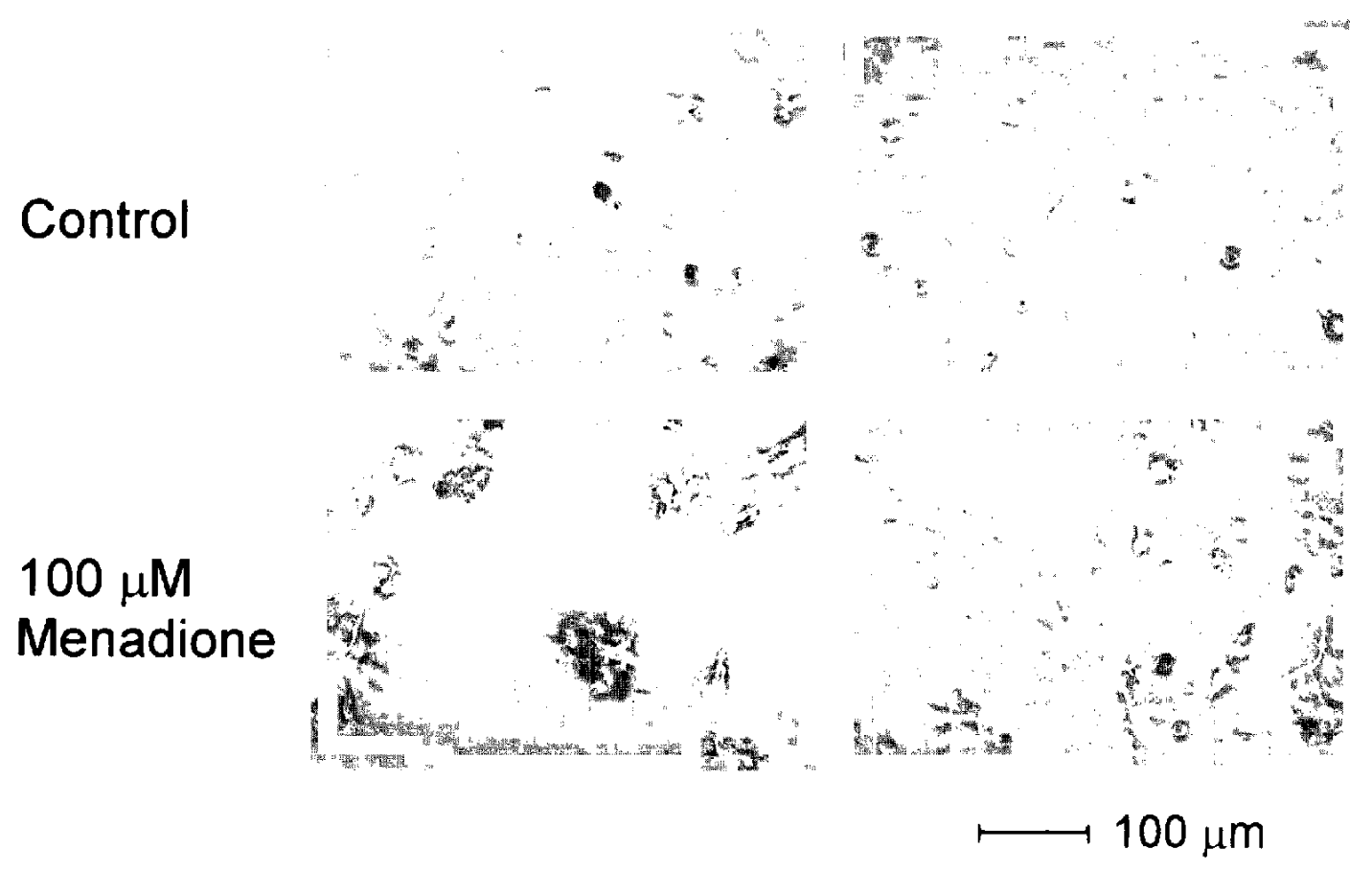

Fig. 7. Effects of menadione and catalase on morphology of cultured astrocytes. Catalase $(200 \mathrm{U} / \mathrm{mi})$ was added $30 \mathrm{~min}$ prior to addition of menadione, and cells were exposed to menadione $(100 \mu \mathrm{M})$ for $8 \mathrm{hr}$. 
A
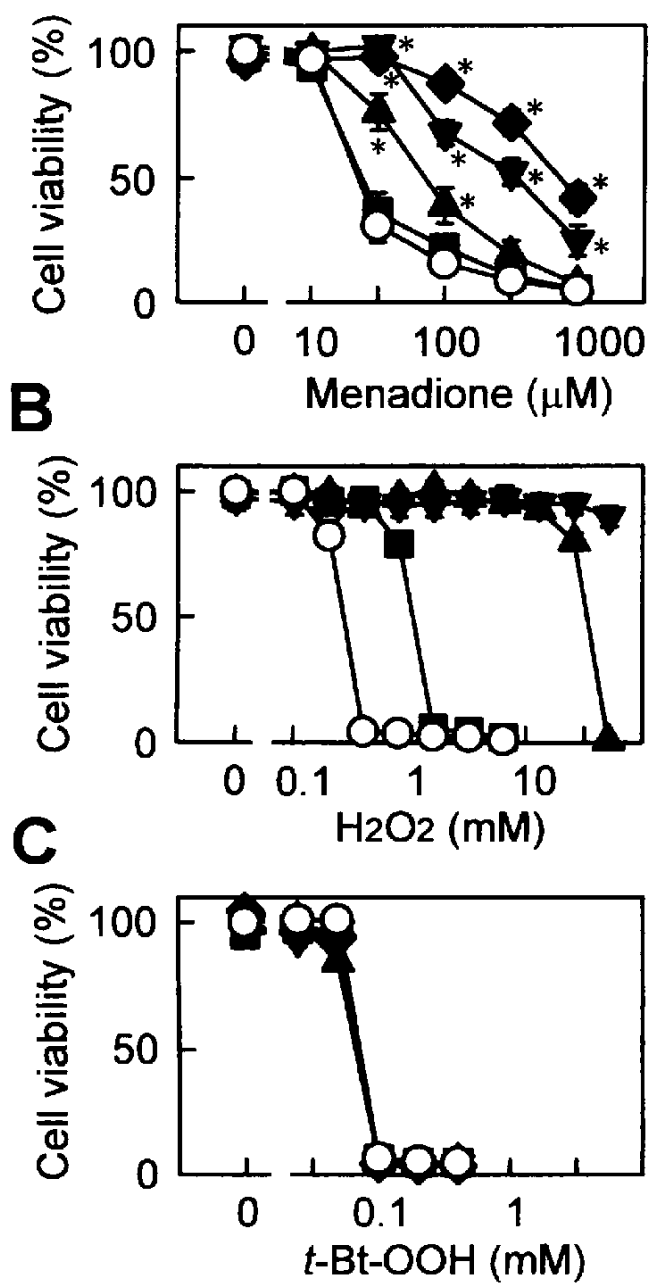

Fig. 8. Effects of catalase $(O$, control; $\boldsymbol{\square}, 2 \mathrm{U} / \mathrm{ml} ; \boldsymbol{\Lambda}, 20 \mathrm{U} / \mathrm{ml}$; $\nabla, 200 \mathrm{U} / \mathrm{ml} ;, 500 \mathrm{U} / \mathrm{ml}$ ) on astrocytic cell death induced by menadione (A), $\mathrm{H}_{2} \mathrm{O}_{2}$ (B) or tert-butyl hydroperoxide (C). After the cells were exposed to test reagents for $8 \mathrm{hr}$, cell viability was determined by the MTT reduction assay. The data represent the mean \pm S.E.M. of five separate observations. ${ }^{*} P<0.01$ vs control (Duncan's multiple range test). The effect of catalase against $\mathrm{H}_{2} \mathrm{O}_{2}$ was significant, but asterisks are not shown for clarity.

toxicity, then iron chelators should attenuate the toxicity. The iron chelator deferoxamine significantly attenuated menadione toxicity (Figs. 9 and 10A). Similarly, another iron chelator TPEN was effective in attenuating menadione toxicity (Fig. 11A). Deferoxamine and TPEN were also effective in attenuating exogenous $\mathrm{H}_{2} \mathrm{O}_{2}$ toxicity (Figs. 10B and 11B), but their effects against exogenous $\mathrm{H}_{2} \mathrm{O}_{2}$ were relatively smaller than those against menadione.

\section{DISCUSSION}

In the present study, we found that menadione can be used as a pharmacological tool to induce astrocytic cell death via formation of reactive oxygen species. The menadione toxicity on astrocytes was blocked by antioxidants, SOD, catalase and iron chelators, indicating that $\mathrm{O}_{2}{ }^{-}, \mathrm{H}_{2} \mathrm{O}_{2}$ and ${ }^{\circ} \mathrm{OH}$ are all involved in this toxicity. Since among the tested scavengers catalase was most effective in protecting cells against menadione, $\mathrm{H}_{2} \mathrm{O}_{2}$ may play a major role in menadione toxicity.

Morphological changes induced by menadione were considerably different from that by extracellularly applied $\mathrm{H}_{2} \mathrm{O}_{2}$. One possible explanation for this difference is that different types of oxygen species are involved in menadione toxicity and exogenous $\mathrm{H}_{2} \mathrm{O}_{2}$ toxicity. In fact, experiments with $\mathrm{SOD}$ demonstrate that $\mathrm{O}_{2}{ }^{-}$is involved in menadione toxicity but not in exogenous $\mathrm{H}_{2} \mathrm{O}_{2}$ toxicity. Another possibility is that intracellularly generated $\mathrm{H}_{2} \mathrm{O}_{2}$ has different impact on the cell than extracellular $\mathrm{H}_{2} \mathrm{O}_{2}$. For example, intracellular $\mathrm{H}_{2} \mathrm{O}_{2}$ may preferentially damage intracellular organella.

Catalase, which is membrane impermeable like most proteins, is supposed to scavenge excessive $\mathrm{H}_{2} \mathrm{O}_{2}$ outside the cell. Since $\mathrm{H}_{2} \mathrm{O}_{2}$ is freely diffusible across the membrane, reduction of extracellular $\mathrm{H}_{2} \mathrm{O}_{2}$ by catalase would lower $\mathrm{H}_{2} \mathrm{O}_{2}$ within cells. Catalase protected cells against extracellularly applied $\mathrm{H}_{2} \mathrm{O}_{2}$ much more potently than against menadione toxicity. On the other hand, deferoxamine and TPEN, which are supposed to chelate cellular ferric ions, were effective in attenuating menadione toxicity rather than extracellular $\mathrm{H}_{2} \mathrm{O}_{2}$ toxicity. These results also suggest that menadione generates $\mathrm{H}_{2} \mathrm{O}_{2}$ inside the cell.

Our present study has focused on astrocytes, but it is also interesting to compare menadione effects on other types of cells. Recently, Husain and Juurlink (19) have reported that oligodendrocyte precursor cells were more readily killed by menadione than astrocytes. However, there are several problems with their study. First of all, they employed mixed glial cultures, in which possible interactions between oligodendrocyte precursors and astrocytes must be considered. Second, they examined the effect of menadione in serum-containing medium, which includes undefined concentrations of substances that may potentiate or attenuate the menadione effect. Third, they assayed menadione effects only at concentrations of $50-80 \mu \mathrm{M}$. We are planning to compare menadione effects on astrocytes, oligodendrocytes and microglia by using cell cultures with higher purity.

In conclusion, menadione toxicity is a valuable model for the study of mechanisms underlying oxidative injury in the brain, and it can be used for the screening of drugs that may protect cells from reactive oxygen species. 


\section{$(-) \quad \quad(+) 10 \mu \mathrm{M}$ Deferoxamine}

\section{Control}

\section{$30 \mu \mathrm{M}$ \\ Menadione}

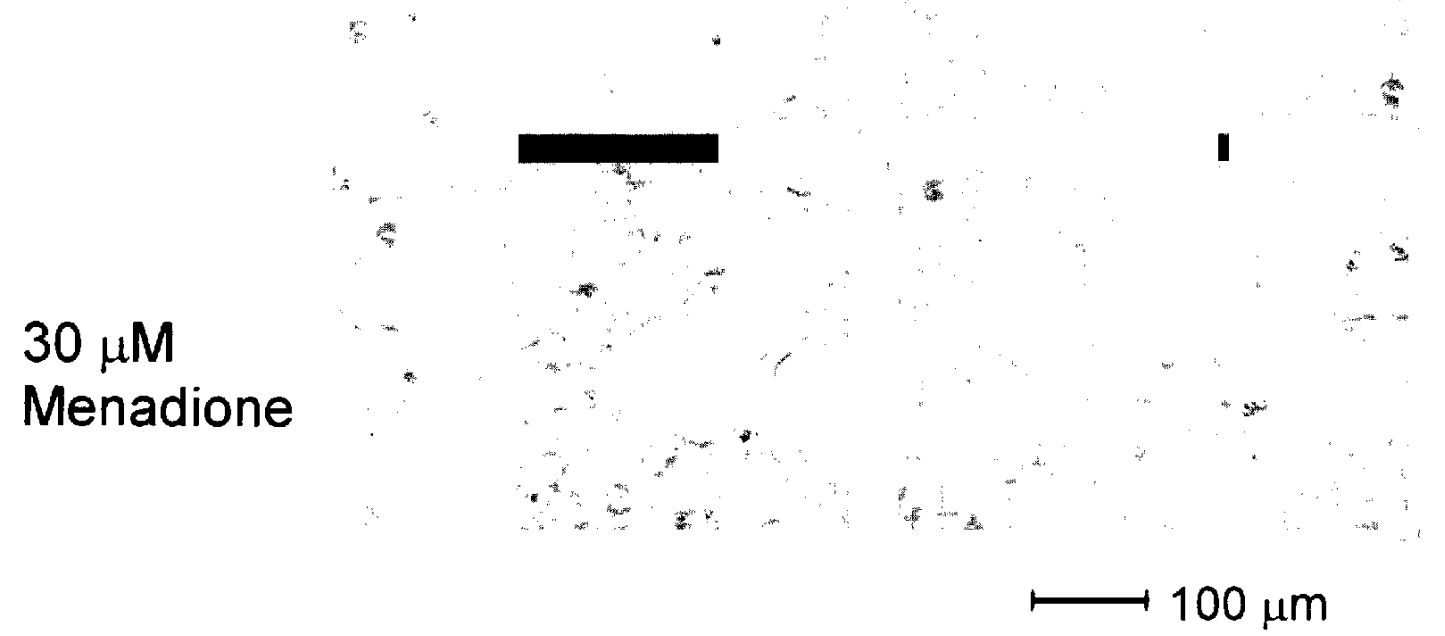

Fig. 9. Effects of menadione and deferoxamine on morphology of cultured astrocytes. Deferoxamine (10 $\mu \mathrm{M})$ was added 30 min prior to menadione, and cells were exposed to menadione $(30 \mu \mathrm{M})$ for $8 \mathrm{hr}$.

A
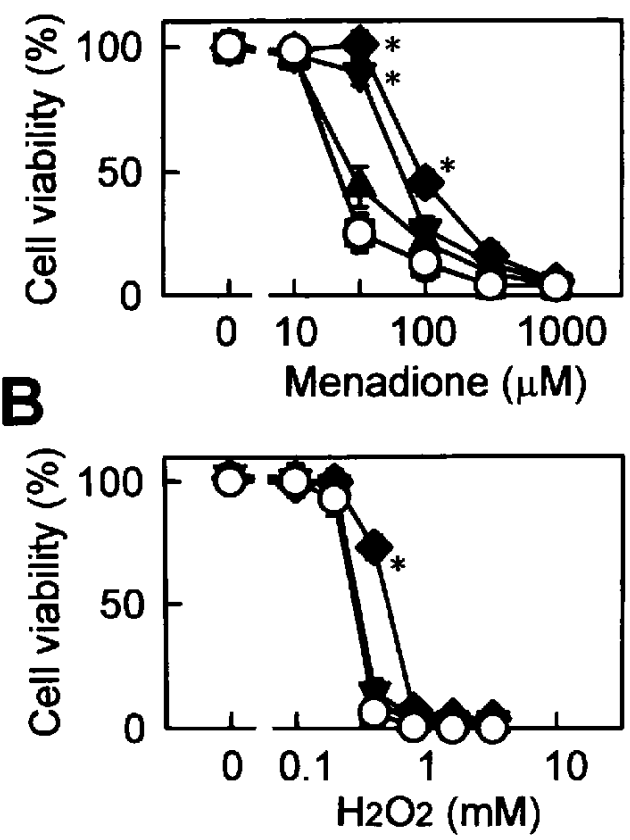

Fig. 10. Effects of deferoxamine $(\bigcirc$, control; $\boldsymbol{a}, 0.1 \mu \mathrm{M} ; \boldsymbol{\Delta}, 1$ $\mu \mathrm{M} ; \boldsymbol{\nabla}, 10 \mu \mathrm{M} ; \bullet, 100 \mu \mathrm{M})$ on astrocytic cell death induced by menadione $(A)$ or $\mathrm{H}_{2} \mathrm{O}_{2}(B)$. The data represent the mean \pm S.E.M. of five separate observations. ${ }^{*} \mathrm{P}<0.01$ vs control (Duncan's multiple range test).
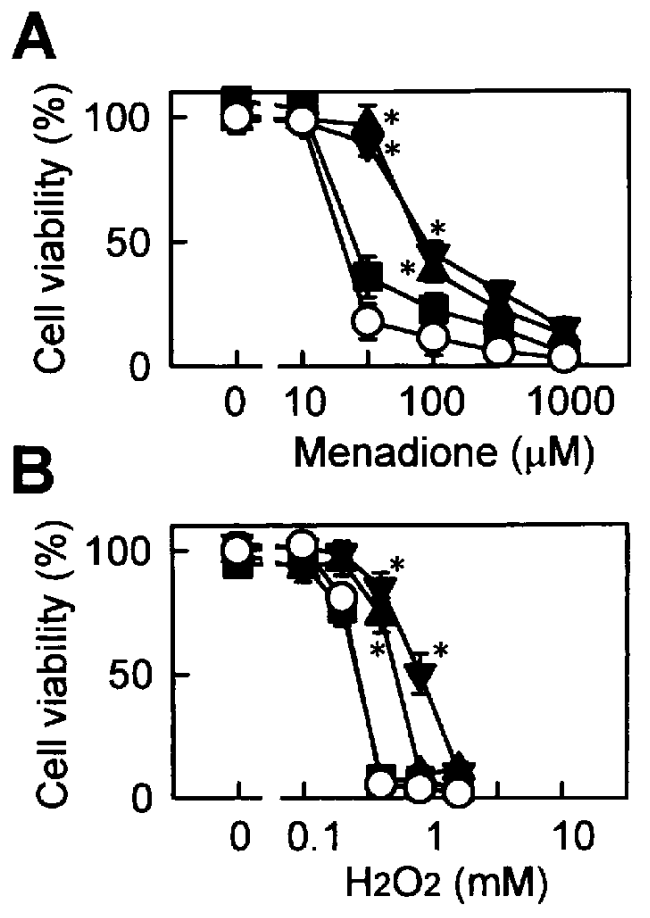

Fig. 11. Effects of TPEN $(\bigcirc$, control; $\square, 0.1 \mu \mathrm{M} ; \boldsymbol{\Delta}, 1 \mu \mathrm{M} ; \boldsymbol{\nabla}, 10$ $\mu \mathrm{M})$ on astrocytic cell death induced by menadione (A) or $\mathrm{H}_{2} \mathrm{O}_{2}(\mathrm{~B})$. Experimental protocol and data representation are the same as in Fig. 10. 


\section{REFERENCES}

1 Halloween B: Reactive oxygen species and the central nervous system. J Neurochem 59, $1609-1623$ (1992)

2 Coyle JT and Puttfarcken P: Oxidative stress, glutamate, and neurodegenerative disorders. Science 262, 689-695 (1993)

3 Olanow $\mathrm{CW}$ : A radical hypothesis for neurodegeneration. Trends Neurosci 16, 439-444 (1993)

4 Nieto-Sampedro M, Manthrope M, Barbin G, Varon S and Cotman CW: Injury-induced neurotrophic activity in adult rat brain: correlation with survival of delayed implants in the wound cavity. J Neurosci 3, 2219-2229 (1983)

5 Needles DL, Nieto-Sampedro M and Cotman CW: Induction of a neurite-promoting factor in rat brain following injury or deafferentation. Neuroscience 18, 517-526 (1986)

6 Ip NY, Wiegard Sj, Morse J and Rudge JS: Injury-induced regulation of ciliary neurotrophic factor mRNA in the adult brain. Eur J Neurosci 5, 25-33 (1993)

7 Hillered L and Ernster L: Respiratory activity of isolated rat brain mitochondria following in vitro exposure to oxygen radicals. J Cereb Blood Flow Metab 3, $207-214$ (1983)

8 Braughler JM, Duncan LA and Goodman T: Calcium enhances in vitro free radical-induced damage to brain synaptosomes, mitochondria, and cultured spinal cord neurons. J Neurochem 45, 1288-1293 (1985)

9 Inagaki $\mathrm{T}$ and Yamazaki I: One-electron-transfer reactions in biochemical systems $V$. Difference in the mechanisms of quinone reduction by the NADH dehydrogenase and the NAD(P)H dehydrogenase (DT-diaphorase). Biochim Biophys Acta 216, 282-294 (1970)

10 Bachur NR, Gordon SL and Gee MV: A general mechanism for microsomal activation of quinone anticancer agents to free radi- cals. Cancer Res 38, 1745-1750 (1978)

11 Thor H, Smith MT, Hartzell P, Bellomo G, Jewell SA and Orrenius S: The metabolism of menadione (2-methyl-1,4naphthoquinone) by isolated hepatocytes. J Biol Chem 257, $12419-12425$ (1982)

12 White E and Clark JB: Menadione-treated synaptosomes as a model for post-ischemaemic neuronal damage. Biochem J 253, $425-433$ (1988)

13 Abe K, Takayanagi $M$ and Saito $H$ : Effects of recombinant human basic fibroblast growth factor and its modified protein CS23 on survival of primary cultured neurons from various regions of fetal rat brain. Jpn J Pharmacol 53, 221-227 (1990)

14 Hansen MB, Nielsen SE and Berg K: Re-examination and further development of a precise and rapid dye method for measuring cell growth/cell kill. J Immunol Methods 119, 203-210 (1989)

15 Bellomo G, Jewell SA, Thor H and Orrenius S: Regulation of intracellular calcium compartmentation: studies with isolated hepatocytes and $t$-butyl hydroperoxide. Proc Natl Acad Sci USA 79, 6842-6846 (1982)

16 Masaki N, Kyle ME and Farber JL: tert-Butyl hydroperoxide kills cultured hepatocytes by peroxidizing membrane lipids. Arch Biochem Biophys 269, 390-399 (1989)

17 Fenton HJH: Oxidation of tartaric acid in the presence of iron. J Chem Soc 65, 899-903 (1894)

18 Haber F and Weiss J: The catalytic decomposition of hydrogen peroxide by iron salts. Proc R Soc Lond Ser A 147, 332-351 (1934)

19 Husain $\mathrm{J}$ and Juurlink BHJ: Oligodendroglial precursor cell susceptibility to hypoxia is related to poor ability to cope with reactive oxygen species. Brain Res 698, 86-94 (1995) 